\title{
Manfaat modal sosial bagi perkembangan usaha ekonomi produktif Karang Taruna Guyub Rukun 78 Desa Bantur
}

\author{
Magdharega Putri Pratiwi \\ Fakultas Ilmu Sosial, Universitas Negeri Malang \\ Malang, Indonesia \\ putripratiwimagdharega@gmail.com \\ Nur Hadi \\ Fakultas Ilmu Sosial, Universitas Negeri Malang \\ Malang, Indonesia \\ nur.hadi.fis@um.ac.id \\ Nanda Harda Pratama Meiji \\ Fakultas Ilmu Sosial, Universitas Negeri Malang \\ Malang, Indonesia \\ nanda.harda.fis@um.ac.id
}

\begin{abstract}
This paper aims to review how the benefits of social capital for the development of productive economy enterprise of Youth Organization "Guyub Rukun 78" Bantur Village. The data analysis technique in this research is Miles and Huberman's interactive model analysis, which consisted of four steps: 1) data collection; 2) data reduction; 3) data display; 4) conclusion or verification. The result shows that the social capital owned by them are: a)the chairman, the vice, and the member of youth organization have a good network/relationship with village and sub-district officials; b) the chairman, the vice, and the member of youth organization always cohesive and working together in carrying out each activity program; c) the chairman, the vice, and the member of youth organization have the slogan "Guyub Rukun" in all kinds of organizational situations. Meanwhile, the benefits of the network in the productive economy owned by youth organizations are: 1) introducing the business to the society; 2) increasing the product demand; 3) Increasing the cash income of youth organizations.
\end{abstract}

Keywords: productive economy; youth organization; social capital

\begin{abstract}
Abstrak
Tulisan ini berusaha mengulas bagaimana manfaat modal sosial bagi perkembangan usaha ekonomi produktif Karang Taruna Guyub Rukun 78 Desa Bantur. Teknik analisis data yang digunakan dalam penelitian ini adalah analisis model interaktif milik Miles dan Huberman, yang terdiri dari empat tahap, yaitu: 1) pengumpulan data; 2) reduksi data; 3) penyajian data, dan; 4) kesimpulan atau verifikasi. Hasil penelitian menunjukkan bahwa modal sosial yang dimiliki antara lain: a) ketua, wakil, dan para anggota karang taruna memiliki jaringan/hubungan baik dengan para perangkat desa dan kecamatan; b) ketua, wakil, dan para
\end{abstract}




\section{Manfaat modal sosial bagi perkembangan usaha ekonomi produktif ...}

anggota karang taruna selalu kompak dan gotong royong dalam menjalankan tiap program kegiatan; c) ketua, wakil, dan para anggota karang taruna memiliki slogan "Guyub Rukun" dalam segala macam situasi organisasi. Sedangkan manfaat dari jaringan (network) pada usaha ekonomi produktif milik karang taruna antara lain: 1) memperkenalkan usaha kepada masyarakat sekitar; 2) meningkatkan permintaan produk; 3) menambah pemasukan kas karang taruna.

Kata Kunci: ekonomi produktif; karang taruna; modal sosial

Diterima 30 September 2021, Dipublikasikan 30 Oktober 2021

\section{PENDAHULUAN}

Pemuda ialah penduduk Indonesia yang memasuki masa penting pertumbuhan dan perkembangan yaitu berusia 16 (enam belas) sampai dengan 30 (tiga puluh) tahun (UndangUndang Republik Indonesia Nomor 40 Tahun 2009 Tentang Kepemudaan, 2009). Pemuda atau yang dapat pula disebut dengan generasi muda ialah generasi penerus bangsa, kader bangsa, kader masyarakat, dan kader keluarga (Udoki, 2014). Harapan terhadap pemuda dalam proses pembangunan bangsa ini memang cukup besar karena pemuda sendiri memegang peranan penting sebagai tonggak pembangunan (Asep, 2017).

Suatu keharusan dalam diri pemuda ditanamkan sejak dini kepribadian yang partisipatif dalam kehidupan masyarakat untuk mempersiapkan pemuda menjadi generasi penerus bangsa. Kepribadian yang partisipatif dapat mendorong pemuda untuk lebih menyadari peran dan tanggung jawabnya terhadap kehidupan berbangsa dan bernegara. Sehingga rasa acuh tak acuh yang merupakan hal negatif pembentuk budaya individualisme dapat dihilangkan. Kemudian pemuda dapat mulai mengambil peran dengan mengembangkan diri menjadi sumber daya manusia yang produktif. Dalam mempersiapkan, membangun dan memberdayakan pemuda agar mampu berperan aktif dalam kehidupan masyarakat sering dihadapkan pada berbagai permasalahan (Udoki, 2014). Beberapa contoh permasalahan di tengah-tengah kehidupan masyarakat yang disebabkan atau melibatkan pemuda di antaranya ialah kenakalan remaja, pergaulan bebas, anak jalanan, tawuran, dan penyalahgunaan narkotika serta obat-obatan terlarang maupun minuman keras. Jika permasalahan tersebut dibiarkan, maka akan mengakibatkan penurunan kualitas diri pada pemuda atau remaja yang berdampak pada kehidupan masyarakat di sekitar.

Masyarakat dalam usaha untuk mencegah atau menyelesaikan permasalahan-permasalahan yang terjadi pada generasi muda membutuhkan suatu wadah. Wadah tersebut diharapkan dapat mengarahkan dan membina para pemuda untuk meningkatkan kualitas diri dan menjadi pribadi yang lebih baik serta bermanfaat dalam kehidupan masyarakat. Pemuda perlu dibina dan dikembangkan kemampuan, keterampilan, bakat, dan pengetahuannya (Udoki, 2014). Wadah tersebut dapat berupa organisasi, pelatihan, pemberdayaan, dan lain-lain dengan iklim yang harmonis sehingga memungkinkan berkembangnya kreativitas pemuda secara wajar dan seoptimal mungkin. Wadah tersebut tentunya perlu mendapatkan perhatian dan diawasi oleh masyarakat agar semakin berkembang dan maju. Salah satu wadah yang sesuai untuk membina 
para pemuda yaitu melalui Organisasi Karang Taruna. Karang taruna ialah organisasi sosial kemasyarakatan sebagai sarana sekaligus wadah pengembangan tiap anggota masyarakat yang tumbuh dan berkembang atas dasar kesadaran dan tanggung jawab sosial dari, oleh, dan untuk masyarakat terutama generasi muda dalam wilayah desa atau kelurahan atau nama lain yang sejenis terutama bergerak dalam bidang penyelenggaraan kesejahteraan sosial (Peraturan Menteri Sosial Republik Indonesia Nomor 23 Tahun 2013 Tentang Pemberdayaan Karang Taruna BAB 1 Pasal 1 Ayat 1).

Berdasarkan kenyataan yang ditemui ketika melakukan observasi, Karang Taruna Guyub Rukun 78 Desa Bantur merupakan organisasi kepemudaan yang terbentuk karena dorongan dan dukungan dari para pemuda RW 07 dan RW 08 Desa Bantur. Para pemuda RW 07 dan RW 08 yang aktif dan peduli terhadap lingkungan sekitar ingin mempunyai wadah tersendiri untuk mengekspresikan diri serta mengembangkan minat maupun bakat mereka. Sehingga dengan penuh semangat pemuda-pemudi RW 07 dan RW 08 Desa Bantur bersama-sama mendirikan organisasi kepemudaan Karang Taruna dengan terpilihnya Rizal Ardiansyah sebagai Ketua Karang Taruna pertama dan Rizky Bagus Rahmad sebagai Wakil Karang Taruna pertama yang memiliki slogan "Guyub Rukun" dan "78" sebagai identitas bahwa para anggota awalnya merupakan kumpulan dari pemuda-pemudi RW 07 dan RW 08 Desa Bantur. Meski tergolong masih baru berdiri, Karang Taruna Guyub Rukun 78 Desa Bantur berhasil membawa pulang Juara III Lomba Karang Taruna Teladan Tingkat Kabupaten Malang pada 18 Desember 2018. Hal inilah yang mendorong peneliti melakukan penelitian lebih jauh. Sangat penting sekali untuk mengetahui bagaimana modal sosial dan manfaat dari jaringan yang dimiliki oleh karang taruna yang dikembangkan dalam proses pencapaian visi misi sehingga dapat menjadi Juara III Lomba Karang Taruna Teladan Tingkat Kabupaten Malang pada 18 Desember 2018.

Peneliti berusaha dapat membedakan penelitian yang dilakukan dengan penelitian terdahulu. Secara umum, perbedaan penelitian ini dengan beberapa penelitian terdahulu yang pernah dilakukan adalah terletak pada lokasi, tipologi masyarakat dan anggota karang taruna, serta pada visi dan misi karang taruna sebagai subjek penelitian. Penelitian ini terfokus pada modal sosial yang dimiliki oleh Karang Taruna Guyub Rukun 78 Desa Bantur dan manfaat jaringan untuk usaha ekonomi produktif yang dikembangkan dalam proses pencapaian visi misi sehingga dapat menjadi Juara III Lomba Karang Taruna Teladan Tingkat Kabupaten Malang. Penelitian ini berbeda dengan penelitian terdahulu yang berfokus pada hal-hal di luar diskursus mengenai modal sosial. Sedangkan inti dari penelitian saat ini terletak pada diskursus modal sosial yang digunakan, yang mana hal tersebut merupakan poin penting dalam mengembangkan usaha masyarakat. Hal tersebut juga dapat dimanfaatkan untuk mendukung mencapai tujuan-tujuan usaha masyarakat. Sehingga tulisan ini menjadi penting untuk dipublikasikan agar dapat dijadikan tambahan ilmu dan inspirasi bagi masyarakat umum untuk dapat memanfaatkan modal sosial yang dimiliki dalam mengembangkan dan memajukan usahanya. 


\section{METODE}

Penelitian ini dilakukan dengan menggunakan pendekatan penelitian kualitatif. Pendekatan kualitatif adalah langkah-langkah penelitian yang menghasilkan data deskriptif berbentuk katakata lisan atau tertulis dari orang-orang dan perilaku yang dapat diteliti (Bogdan dan Taylor, dalam Moleong, (2017:4). Data dalam penelitian ini dikumpulkan dengan teknik observasi, wawancara, hingga analisis foto dokumentasi. Data dikelola menggunakan analisis model Miles dan Huberman untuk menjawab tujuan penelitian. Penelitian ini dilakukan di Desa Bantur, Kecamatan Bantur, Kabupaten Malang, Provinsi Jawa Timur. Namun untuk lebih fokusnya penelitian ini banyak dilakukan peneliti di RW 07 dan RW 08 Dusun Bantur Timur, Desa Bantur, Kecamatan Bantur, Kabupaten Malang. Hal ini didasari oleh seluruh usaha yang didirikan Karang Taruna dan dijalankan oleh anggota karang taruna bertempat di lokasi tersebut (Tabel 1).

Tabel 1. Daftar Usaha Karang Taruna

\begin{tabular}{|c|c|c|c|}
\hline No. & Jenis Usaha & $\begin{array}{l}\text { Penanggung } \\
\text { Jawab Usaha }\end{array}$ & Lokasi Usaha \\
\hline 1. & Usaha Telur Asin & Dwi Antono & Dusun Bantur Timur RT 34 RW 07 Desa Bantur \\
\hline 2. & $\begin{array}{l}\text { Usaha Percetakan dan } \\
\text { Sablon. }\end{array}$ & Joko Malis & Dusun Bantur Timur RT 34 RW 07 Desa Bantur. \\
\hline 3. & Usaha Martabak Mini. & $\begin{array}{l}\text { Ilham Mufti } \\
\text { Muhammad }\end{array}$ & Dusun Bantur Timur RT 37 RW 08 Desa Bantur \\
\hline 4. & Usaha Las. & Mashudi & Dusun Bantur Timur RT 34 RW 07 Desa Bantur \\
\hline 5. & Usaha Laundry. & Devi Nur Safitri & Dusun Bantur Timur RT 32 RW 07 Desa Bantur \\
\hline
\end{tabular}

Data yang digali dalam penelitian ini berupa data mengenai modal sosial yang dimiliki oleh karang taruna guyub rukun 78 desa Bantur. Data-data tersebut digali untuk menjawab pertanyaan penelitian. Analisis data dilakukan dengan melibatkan pengumpulan data terbuka berdasarkan pada rumusan masalah dan mengembangkan analisis dari informasi yang diberikan oleh informan. Analisis data yang digunakan dalam penelitian ini adalah dengan reduksi data, sajian data, dan penarikan kesimpulan/verifikasi. Pengecekan keabsahan data dilakukan dengan cara perpanjangan keikutsertaan dan triangulasi. Proses penggalian data dilakukan dengan cara observasi, wawancara, dan dokumentasi. Analisis data pada penelitian ini dilakukan secara kontinu bersamaan dengan proses penggalian data, pembuatan interpretasi, dan penulisan laporan. Sementara wawancara sedang berlangsung, peneliti dapat melakukan analisis terhadap wawancara yang dikumpulkan sebelumnya, menulis memo yang mungkin akhirnya dimasukkan dalam laporan akhir. 


\section{HASIL DAN PEMBAHASAN}

\section{Modal sosial karang taruna Guyub Rukun 78 Desa Bantur}

Bagian ini berusaha membahas mengenai modal sosial yang dimiliki oleh Karang Taruna Guyub Rukun 78 Desa Bantur sehingga mampu berprestasi dalam kaitannya dengan teori modal sosial yang diperkenalkan oleh Robert Putnam. Hal ini sesuai dengan tujuan dalam penelitian ini mengenai macam-macam modal sosial yang dimiliki oleh karang taruna guyub rukun 78 desa Bantur.

Modal sosial adalah salah satu konsep yang dapat digunakan untuk mengukur kualitas hubungan dalam organisasi Karang Taruna Guyub Rukun 78 Desa Bantur. Peneliti telah berupaya mengumpulkan data mengenai modal sosial yang dimiliki oleh organisasi Karang Taruna Guyub Rukun 78 Desa Bantur sehingga mampu berprestasi. Kebesaran dan eksistensi organisasi karang taruna tidak terlepas dari banyaknya modal yang dimiliki. Di sini, modal sosial lebih ditekankan pada potensi karang taruna dan hubungan antar anggota dalam karang taruna serta hubungan antar kelompok (dengan para perangkat desa maupun masyarakat). Menurut Putnam, modal sosial melibatkan jaringan (networks), norma-norma (norms), dan kepercayaan (trust) yang mendorong kolaborasi sosial (koordinasi dan kooperasi) guna kepentingan bersama.

Modal sosial yang dimiliki oleh Karang Taruna Guyub Rukun 78 Desa Bantur sehingga mampu berprestasi antara lain: a) ketua, wakil, dan para anggota karang taruna memiliki jaringan/hubungan baik dengan para perangkat desa dan kecamatan; b) ketua, wakil, dan para anggota karang taruna selalu kompak dan gotong royong dalam menjalankan tiap program kegiatan; c) ketua, wakil, dan para anggota karang taruna memiliki slogan "Guyub Rukun" dalam segala macam situasi organisasi; d) para anggota karang taruna sangat sopan, santun, dan menjalin hubungan yang baik dengan masyarakat sekitar Desa Bantur; e) para anggota karang taruna terdiri dari pemuda-pemudi yang berpendidikan, kreatif, dan berwawasan luas; f) para anggota karang taruna dengan jiwa kewirausahaan yang tinggi; g) para anggota karang taruna dengan jiwa sosialnya yang tinggi; dan h) para anggota karang taruna peduli terhadap lingkungan sekitar.

Jaringan (networks) adalah hubungan sosial, relasi sosial, keterkaitan sosial, dan kontak sosial antar anggota dalam organisasi Karang Taruna Guyub Rukun 78 Desa Bantur juga antara anggota karang taruna dengan para perangkat desa dan masyarakat sekitar. Peneliti dalam penelitian ini melihat dan merasakan langsung hubungan yang terjalin baik antar anggota dalam organisasi Karang Taruna Guyub Rukun 78 Desa Bantur. Baik ketua, wakil, dan para anggota karang taruna sangat kompak dalam berorganisasi. Kekompakan yang dimiliki oleh para anggota karang taruna terlihat ketika peneliti mengikuti jalannya rapat kecil maupun rapat besar karang taruna. Usulan agar dibuka usaha baru yaitu laundry dari salah satu anggota karang taruna langsung mendapat dukungan penuh dari para anggota karang taruna yang lain. Tidak hanya mendukung ide dari salah satu anggota, anggota yang lain turut mencari solusi siapa yang akan tanggung jawab atas usaha laundry, berapa kisaran dana yang dibutuhkan untuk membuka usaha, dan di mana lokasi usaha yang strategis. Sangat kompak sekali.

Kekompakan antara anggota karang taruna tampak dari ide dan pikiran mereka yang selalu sejalan, Sehingga tidak sulit bagi mereka untuk menyelenggarakan berbagai program kegiatan. Selain itu, kekompakan para anggota karang taruna tercermin melalui jiwa sosial tinggi yang sama-sama mereka miliki. Para anggota karang taruna selalu bersemangat menyelenggarakan berbagai program kegiatan yang tujuannya adalah untuk kesejahteraan sosial (masyarakat 


\section{Manfaat modal sosial bagi perkembangan usaha ekonomi produktif ...}

sekitar). Misalnya saja ketika menyelenggarakan program kegiatan "Bedah Rumah". Berkat para anggota karang taruna yang selalu kompak dan sejalan, program kegiatan "Bedah Rumah" dapat diselenggarakan dengan sukses. Kekompakan yang dimiliki oleh para anggota karang taruna diwujudkan dalam sikap gotong royong. Para anggota karang taruna menyebar mencari donatur dan bantuan untuk kelancaran kegiatan bedah rumah. Kemudian mereka pula yang berbelanja material bangunan serta menyumbangkan tenaga untuk menjadi kuli dari program kegiatan mereka sendiri.

Hubungan yang terjalin baik antara anggota Karang Taruna Guyub Rukun 78 Desa Bantur juga tampak dalam slogan "Guyub Rukun" pada nama karang taruna. Kalimat "Guyub Rukun" dalam nama karang taruna bukan hanya sekedar nama, namun menjadi pedoman pemersatu antara anggota dalam karang taruna. Organisasi apapun pasti pernah mengalami suatu gesekan. Wakil karang taruna, Rizky, tidak memungkiri bahwa dalam organisasi yang dipimpinnya pernah mengalami suatu gesekan antar anggota. Contohnya ketika para anggota sedang menjalankan suatu kegiatan karang taruna. Sering kali anggota dalam organisasi bertengkar, selisih pendapat, bahkan saling menyalahkan. Namun, hal tersebut selalu dapat ditengahi. Rizky mengajak para anggota untuk selalu ingat dengan slogan yang dimiliki oleh karang taruna, yaitu gurub rukun.

Slogan "Guyub Rukun" menjadi alasan selesainya perselisihan dalam tiap anggota. Gesekan-gesekan maupun pertengkaran yang terjadi ketika karang taruna melakukan kegiatan, akhirnya dapat redam dan para anggota kembali rukun. Segala macam konflik selalu dibahas dalam rapat dan musyawarah. Tiap kali Karang Taruna Guyub Rukun 78 Desa Bantur selesai menyelenggarakan suatu kegiatan, para anggota selalu berkumpul untuk melakukan evaluasi kegiatan. Evaluasi dilakukan agar masing-masing dapat belajar kelebihan dan kekurangan dari program kegiatan yang telah dijalankan. Sehingga di kemudian hari semua dapat belajar memperbaiki demi keberhasilan program kegiatan selanjutnya. Tak lupa kegiatan evaluasi diakhiri dengan pengungkapan-pengungkapan bahwa mereka semua adalah keluarga besar, mereka semua adalah saudara. Pencapaian apapun selalu disyukuri bersama sehingga para anggota semakin guyub rukun.

Jaringan (networks) atau hubungan sosial, relasi sosial, keterkaitan sosial, dan kontak sosial juga terjalin baik antara anggota Karang Taruna Guyub Rukun 78 Desa Bantur dengan para perangkat desa juga dengan masyarakat sekitar. Misalnya saja pada saat PEMILU 17 April 2019 lalu. Relasi dengan orang-orang penting di Desa Bantur terjalin sangat baik karena para anggota karang taruna selalu aktif dalam kegiatan desa maupun kecamatan. Setiap kali para perangkat desa diundang dalam kegiatan karang taruna, tidak ada yang mengabaikan undangan tersebut. Bahkan banyak perangkat desa yang malah mendukung program kegiatan yang dibuat oleh Karang Taruna Guyub Rukun 78 Desa Bantur. Hal ini dibuktikan oleh peneliti dengan datangnya bantuan dana dari pihak desa yang tidak sedikit jumlahnya ketika Karang Taruna Guyub Rukun 78 Desa Bantur menjalankan program kegiatan pemberdayaan ikan di sungai.

Norma-norma (norms) dalam modal sosial merupakan aturan yang mengatur seseorang untuk berperilaku dalam interaksinya dengan orang lain pada suatu masyarakat. Hubungan yang terjalin baik antara anggota Karang Taruna Guyub Rukun 78 Desa Bantur dengan para perangkat desa menandakan di antara keduanya telah menjalankan norma dengan baik. Sebab jika salah satu tidak menjalankan norma dengan baik, maka dapat disebut sedang berperilaku menyimpang. Perilaku yang menyimpang tidak akan mampu menghasilkan hubungan yang baik, apalagi hubungan yang saling menguntungkan. Begitu pula dengan jalinan hubungan 
yang terjadi dalam organisasi Karang Taruna Guyub Rukun 78 Desa Bantur. Masing-masing anggota, baik ketua, wakil, dan yang lainnya saling mematuhi norma yang ada sehingga interaksi yang terjadi berjalan dengan baik. Sopan dan santun dijunjung tinggi dalam organisasi. Ada kalanya bercanda, ada kalanya serius, dan para anggota karang taruna memahami hal tersebut. Dalam rapat karang taruna, apabila salah satu anggota sedang mengutarakan pendapat, maka anggota yang lain mendengarkan dengan tenang tanpa memotong pembicaraan. Masing-masing anggota telah paham bahwa seluruhnya akan diberi kesempatan untuk berbicara. Sehingga tidak ada yang berdebat. Selain itu, meskipun sering berkumpul, berkegiatan bersama, bahkan akrab, sopan-santun tetap diterapkan dengan baik utamanya pada anggota yang berumur lebih tua.

Kemudian poin yang tidak kalah penting dalam modal sosial adalah kepercayaan (trust). Kepercayaan (trust) merupakan suatu bentuk perasaan yakin bahwa yang lain akan melakukan hal seperti yang diharapkan dan akan selalu bertindak dalam suatu pola tindakan yang saling menguntungkan atau saling merugikan. Kepercayaan (trust) menjadi hal yang sangat penting dan mendasar dalam jalinan hubungan sosial. Jika perasaan saling percaya telah luntur dan hilang maka yang akan terjadi adalah sikap saling menyimpang dari nilai, norma dan kesepakatan yang berlaku. Kemudian kerja sama antara keduanya tidak terjalin lagi. Dalam penelitian ini, kepercayaan adalah hal yang sangat penting bagi jalannya organisasi Karang Taruna Guyub Rukun 78 Desa Bantur.

Yang pertama adalah perasaan saling percaya antar anggota dalam organisasi. Perasaan saling percaya terlihat ketika terpilihnya Rizal dan Rizky untuk menjabat sebagai ketua dan wakil karang taruna pertama. Di sini artinya para anggota telah yakin dan percaya pada Rizal dan Rizky sehingga mereka diberi amanah untuk memimpin Karang Taruna Guyub Rukun 78 Desa Bantur selama lima (5) tahun dari tahun 2016 hingga 2021. Dipilihnya Rizal dan Rizky sebagai ketua dan wakil karang taruna pertama sebab masing-masing anggota telah saling memperhatikan. Kemudian seluruhnya percaya dan yakin terhadap kemampuan Rizal dan Rizky untuk memimpin jalannya organisasi. Namun tidak berhenti di sini saja. Para anggota tentunya berharap agar Rizal dan Rizky dapat membawa organisasi pada kesuksesan. Harapan ini kemudian dibuktikan oleh Rizal dan Rizky. Selama memimpin organisasi, mereka berdua terlihat lebih aktif daripada yang lain. Selain itu banyak sekali kelebihan-kelebihan yang mereka tunjukkan pada masyarakat sekitar. Organisasi menjadi sarana aktualisasi diri untuk Rizal dan Rizky. Namun yang terpenting di bawah kepemimpinan Rizal dan Rizky, organisasi Karang Taruna Guyub Rukun 78 Desa Bantur berhasil mendapatkan Juara III Lomba Karang Taruna Teladan Tingkat Kabupaten Malang.

Kepercayaan antar anggota karang taruna juga tampak ketika pembagian tugas. Masingmasing anggota mendapatkan pembagian tugas ketika karang taruna sedang menyelenggarakan suatu program kegiatan. Pembagian tugas ini menandakan bahwa si A (yang mendapatkan tugas) dipercaya dapat menjalankan tugas tersebut. Namun tentunya meskipun terjadi pembagian tugas, para anggota tetap bergotong-royong sebab itu adalah modal sosial yang mereka miliki. Gotong royong adalah sebuah keharusan dalam tiap program kegiatan karang taruna. Bahkan dalam wawancara, apabila salah satu anggota tidak dapat hadir dalam suatu kegiatan, maka tidak masalah. Anggota yang lain berusaha untuk memahami bahwa kesibukan tiap orang memam berbeda sehingga sulit untuk mengumpulkan seluruhnya.

Kepercayaan dalam organisasi juga tampak ketika Karang Taruna Guyub Rukun 78 Desa Bantur menjalankan usaha ekonomi produktif. Karang Taruna Guyub Rukun 78 Desa Bantur 


\section{Manfaat modal sosial bagi perkembangan usaha ekonomi produktif ...}

saat ini telah memiliki lima (5) usaha yang masing-masing dikelola oleh anggota karang taruna. Usaha pertama adalah usaha telur asin yang dikelola oleh Dwi Antono. Usaha kedua adalah usaha sablon dan percetakan yang dikelola oleh Joko Malis. Usaha ketiga adalah usaha martabak mini yang dikelola oleh Ilham. Usaha keempat adalah usaha las listrik yang dikelola oleh Mashudi. Sedangkan usaha terakhir yang baru dibuka November 2019 kemarin adalah usaha laundry dengan Devi sebagai pengelolanya. Dwi Antono dan empat anggota lain (Joko Malis, Ilham, Mashudi, dan Devi) dapat mengelola usaha ekonomi produktif milik karang taruna tentunya karena kepercayaan yang telah diberikan oleh para anggota kepada mereka. Mereka berlima dirasa mampu untuk bertanggung jawab atas jalannya usaha. Sehingga amanah besar tersebut jatuh pada mereka.

Dwi Antono dan yang lain juga mampu menunjukkan bahwa mereka pantas untuk dipercaya. Usaha telur asin yang dikelola Dwi Antono dengan dibantu beberapa anggota karang taruna lain semakin lama semakin berkembang. Saat ini usaha telur asin mampu memproduksi 4.000 sampai dengan 5.000 butir telur asin setiap bulannya. Usaha sablon dan percetakan juga banyak diminati masyarakat sekitar. Bahkan kaos hasil produksinya laris terjual dalam acara bazar Bantur Tempo Doeloe (BTD). Untuk usaha martabak mini, Ilham menuturkan setiap harinya dia menyediakan 30 porsi dan selalu laku habis. Usaha las listrik juga tidak kalah. Mashudi sebagai pengelola usaha las listrik adalah mantan TKI Korea dan di Korea waktu itu pernah bekerja di pabrik khususnya las serta ikut membuat gandengan trailer. Sehingga kemampuan Mashudi tidak perlu diragukan lagi dalam hal las listrik. Untuk usaha yang terakhir, memang ada beberapa usaha laundry yang sebelumnya telah buka di Desa Bantur. Namun para anggota karang taruna banyak yang membantu mengiklankan usaha laundry karang taruna di status facebook, instagram, whatsapp, sehingga masyarakat Desa Bantur mengetahui informasi tersebut. Laundry karang taruna melayani antar-jemput ke rumah para pelanggan.

Kepercayaan (trust) juga terjalin antara organisasi Karang Taruna Guyub Rukun 78 Desa Bantur dengan masyarakat sekitar. Berkat hubungan yang dibangun baik dengan masyarakat sekitar, banyak masyarakat yang kemudian memberikan kepercayaannya kepada Karang Taruna Guyub Rukun 78. Hal ini diketahui oleh peneliti dengan banyaknya donatur yang membantu kesuksesan tiap program kegiatan yang dijalankan oleh karang taruna. Selain itu hal ini juga disampaikan sendiri oleh ketua dan wakil karang taruna, Mas Rizal dan Mas Rizky, bahwa banyak dari masyarakat sekitar (RW 07 dan RW 08) yang selalu bersedia menjadi donatur dalam tiap program kegiatan karang taruna. Bahkan tidak hanya sekali dua kali saja menjadi donatur. Namun menjadi donatur tetap tiap program kegiatan karang taruna.

Kemudian jaringan, norma-norma, dan kepercayaan di atas berkolaborasi sosial (koordinasi dan kooperasi) sehingga melahirkan eksistensi Karang Taruna Guyub Rukun 78 Desa Bantur. Jaringan sosial yang antar anggota dalam organisasi Karang Taruna Guyub Rukun 78 Desa Bantur juga antara anggota karang taruna dengan para perangkat desa dan masyarakat sekitar memungkinkan terjadinya komunikasi dan koordinasi yang dapat menumbuhkan rasa saling percaya di antara seluruhnya. Orang-orang yang mempunyai rasa saling percaya (mutual trust) dapat memperkuat norma-norma mengenai keharusan untuk saling membantu. Sehingga terciptalah kerja sama di antara anggota karang taruna dengan para perangkat desa dan masyarakat. Kerja sama tersebut melahirkan keberhasilan dan kesuksesan pada tiap program kegiatan yang diselenggarakan Karang Taruna Guyub Rukun 78 Desa Bantur. Kesuksesan 
yang dimaksud mengacu pada tanggapan masyarakat yang sangat antusias pada tiap program kegiatan karang taruna.

Putnam dalam Field (2010) menjelaskan perbedaan antara dua bentuk dasar modal yaitu mengikat (eksklusif) dan menjembatani (inklusif). Modal sosial yang mengikat (eksklusif) cenderung mendorong dan mempertahankan homogenitas. Modal sosial mengikat atau eksklusif terjadi dalam lingkup organisasi Karang Taruna Guyub Rukun 78 Desa Bantur yaitu antara ketua, wakil, dan para anggota karang taruna. Seluruhnya baik ketua, wakil, dan para anggota karang taruna cenderung mendorong dan mempertahankan homogenitas melalui kekompakan, gotong royong, dan guyub rukun yang tercermin pada tingkah laku mereka. Sedangkan modal sosial yang menjembatani (inklusif) cenderung menyatukan banyak orang dari berbagai ranah sosial. Modal sosial menjembatani atau inklusif cenderung menyatukan banyak orang, yaitu menyatukan organisasi Karang Taruna Guyub Rukun 78 Desa Bantur dengan para perangkat desa dan masyarakat sekitar.

Lebih dari itu, eksistensi karang taruna juga berkat keberhasilannya mendapatkan Juara III Lomba Karang Taruna Teladan Tingkat Kabupaten Malang. Hal-hal yang menjadi indikator penilaian kejuaraan antara lain visi-misi, program jangan pendek, menengah, panjang, administrasi kegiatan, kegiatan ROKE (Rekreasi, Olahraga, Kesenian, Edukasi), pendampingan PMKS PSKS, usaha ekonomi produktif, usaha kesejahteraan sosial, serta pengembangan inovasi karang taruna. Karang Taruna Guyub Rukun 78 Desa Bantur berhasil mencapai masing-masing indikator dengan baik. Program kegiatan yang diselenggarakan karang taruna selalu berhasil mencuri perhatian masyarakat sekitar.

Berkat kejuaraan dan keunikan dari program kegiatan karang taruna, akhirnya banyak pemuda-pemudi dari RT/RW/Dusun lain bergabung dengan Karang Taruna Guyub Rukun 78 Desa Bantur. Sehingga Karang Taruna Guyub Rukun 78 Desa Bantur saat ini semakin besar, dikenal oleh hampir seluruh masyarakat Desa Bantur, bahkan masyarakat luar sekalipun. Karang Taruna Guyub Rukun 78 Desa Bantur membutuhkan penerus agar organisasi tidak mati dan buyar seperti organisasi-organisasi yang telah ada sebelumnya. Semakin banyak anggota baru yang bergabung, maka semakin banyak pemuda-pemudi yang ikut mengambil peran dalam usaha untuk membangun desa. Karang Taruna Guyub Rukun 78 Desa Bantur menjadi wadah untuk belajar bersama, belajar hal yang positif, dan kemudian merealisasikannya dalam bentuk program kegiatan.

\section{Manfaat jaringan (network) pada usaha ekonomi produktif}

Usaha ekonomi produktif adalah salah satu kegiatan yang dijalankan oleh Karang Taruna Guyub Rukun 78 Desa Bantur. Sejak awal berdiri, organisasi karang taruna mulai merintis usaha dari nol. Saat ini karang taruna telah memiliki lima (5) usaha ekonomi produktif. Usaha ekonomi produktif milik karang taruna antara lain: 1) usaha telur asin; 2) usaha sablon dan percetakan; 3) usaha martabak mini; 4) usaha las listrik; dan 5) usaha laundry. Kelima usaha tersebut dikelola sendiri oleh para anggota karang taruna.

Usaha ekonomi produktif milik karang taruna tidak begitu saja besar dan banyak jenisnya seperti sekarang ini. Salah satu hal yang memberikan banyak manfaat dalam perjalanan usaha ekonomi produktif milik karang taruna adalah jaringan (network) yang merupakan unsur dari modal sosial. Jaringan (network) di sini adalah jaringan sosial, yaitu hubungan sosial, relasi 


\section{Manfaat modal sosial bagi perkembangan usaha ekonomi produktif ...}

sosial, keterikatan sosial, dan kontak sosial. Jaringan sosial dalam penelitian ini antara lain jalinan hubungan sosial antar anggota karang taruna dan antara anggota karang taruna dengan kelompok sosial lain misalnya masyarakat sekitar.

Jaringan (network) dalam modal sosial Karang Taruna Guyub Rukun 78 Desa Bantur memberikan banyak sekali manfaat untuk usaha ekonomi produktif milik karang taruna. Manfaat tersebut antara lain: 1) membantu memperkenalkan usaha (produk/jasa) karang taruna kepada masyarakat sekitar; 2) meningkatkan permintaan produk; 3) meningkatkan produktivitas usaha; 4) banyak keuntungan yang didapat, misalnya penghematan tenaga serta waktu; dan 5) menambah pemasukan kas karang taruna setiap bulannya, sehingga dapat dimanfaatkan untuk menyelenggarakan program kegiatan atau membuka usaha baru karang taruna.

Salah satu hal yang menjadi ciri-ciri dari organisasi sosial adalah adanya suatu jaringan (network). Jaringan (network) yang merupakan salah satu unsur dari modal sosial yang dapat mempermudah koordinasi dan kerja sama untuk mencapai keuntungan bersama. Hal inilah yang terjadi pada perjalanan usaha ekonomi produktif milik Karang Taruna Guyub Rukun 78 Desa Bantur. Pada bagian atas telah disebutkan bahwa jaringan (network) yang dimiliki oleh karang taruna yaitu berupa jalinan hubungan antar anggota karang taruna serta jalinan hubungan antara anggota karang taruna dengan masyarakat sekitar.

Jalinan hubungan yang baik antar anggota karang taruna dapat mempermudah terjadinya kerja sama di antara mereka. Jalinan hubungan yang baik tersebut berupa sikap kompak, gotong royong, dan guyub rukun yang dapat mempermudah terjadinya kerja sama. Kerja sama yang dimaksud yaitu mempromosikan usaha (produk/jasa) milik karang taruna kepada masyarakat. Promosi dilakukan dengan memanfaatkan media sosial yang dimiliki oleh tiap-tiap anggota karang taruna seperti Instagram, WhatsApp, Facebook, dan lain-lain. Semuanya sangat kompak dalam hal ini. Bahkan promosi juga dilakukan dengan menawarkan produk atau jasa dari karang taruna kepada keluarga besar, saudara, teman, secara langsung ketika bertemu atau sedang berkumpul. Kerja sama ini berjalan guna mencapai keuntungan bersama yaitu meningkatnya permintaan produk usaha karang taruna yang nanti dapat menambah pemasukan kas karang taruna setiap bulan.

Jaringan sosial memungkinkan terjadinya komunikasi dan koordinasi yang dapat menumbuhkan rasa saling percaya di antara sesama anggota masyarakat. Dalam penelitian ini, para pemuda-pemudi terikat pada suatu jaringan sosial yaitu organisasi Karang Taruna Guyub Rukun 78 Desa Bantur. Dengan terikatnya para pemuda-pemudi dalam organisasi karang taruna, maka terciptalah komunikasi di antara mereka. Komunikasi tersebut dapat dilihat pada kegiatan rapat dan musyawarah rutin organisasi. Selain komunikasi, hal lain yang tercipta adalah koordinasi. Para anggota karang taruna selalu berkoordinasi untuk setiap program kegiatan yang akan atau sedang dijalankan.

Komunikasi dan koordinasi juga terjadi ketika antar anggota karang taruna sepakat untuk sama-sama saling mempromosikan usaha karang taruna kepada masyarakat. Komunikasi yang sering dilakukan antar anggota karang taruna membuat mereka lebih saling mengenal dalam antara satu dengan yang lainnya. Dengan lebih saling mengenal, batas di antara anggota karang taruna seolah hilang. Jika awalnya para anggota karang taruna hanya berkumpul dalam suatu rapat dan musyawarah, maka kemudian mereka telah terbiasa berkumpul di luar urusan organisasi, seperti ngopi atau sekedar nonton bersama. Kedekatan jalinan hubungan antar 
anggota karang taruna di luar urusan organisasi menandakan bahwa di antara mereka telah tumbuh rasa saling percaya.

Kepercayaan (trust) mempunyai implikasi positif dalam kehidupan bermasyarakat. Dalam suatu jaringan sosial, orang-orang yang mempunyai rasa saling percaya (mutual trust) dapat memperkuat norma-norma mengenai keharusan untuk saling membantu. Dalam penelitian ini, para pemuda-pemudi karang taruna memiliki rasa saling percaya (mutual trust) antara satu dengan yang lainnya. Perasaan saling percaya itulah yang mendorong mereka akhirnya bertindak saling membantu baik dalam menjalankan suatu program kegiatan maupun menjalankan usaha ekonomi produktif milik karang taruna.

Tindakan saling membantu contohnya ketika pemuda-pemudi kompak bersama-sama mempromosikan dan melariskan usaha milik karang taruna. Tindakan saling membantu juga terjadi ketika para anggota bergotong royong melakukan produksi telur asin di kediaman Mas Dwi Antono. Jika membaca ulang paparan data di atas, maka dapat kita lihat tindakan saling membantu antar anggota juga terjadi ketika karang taruna menjalankan suatu program kegiatan. Misalnya pada kegiatan bedah rumah. Para anggota karang taruna bergotong-royong mencari donatur untuk keberhasilan kegiatan mereka, bahkan sampai menjadi kuli pada kegiatan tersebut. Tindakan saling membantu sangat totalitas dilakukan oleh mereka sehingga acara bedah rumah sukses diselenggarakan. Kesuksesan sebuah program kegiatan adalah tujuan sekaligus apa yang berhasil dicapai oleh Karang taruna Guyub Rukun 78 Desa Bantur.

Kerja sama dalam suatu jaringan yang dapat mencapai berbagai keberhasilan akan mendorong berlangsungnya kerja sama pada waktu selanjutnya. Hal itu pula yang terjadi dalam organisasi Karang Taruna Guyub Rukun 78 Desa Bantur. Kerja sama yang baik ketika menyelenggarakan kegiatan bedah rumah membuat para anggota karang taruna merasakan keberhasilan dan kesuksesan dalam kegiatan tersebut. Keberhasilan ketika menyelenggarakan suatu kegiatan membuat para anggota karang taruna mengulang kerja sama pada kegiatankegiatan selanjutnya seperti kegiatan Bantur Tempo Doeloe (BTD), Kirab Budaya, dan lainlain. Pengulangan ini kerja sama ini merupakan bukti adanya jaringan (network) yang baik dalam organisasi sekaligus sebagai harapan agar dapat mencapai keberhasilan selanjutnya.

Kerja sama dalam organisasi karang taruna tentunya juga melahirkan keberhasilan pada bidang usaha ekonomi produktif miliki karang taruna. Para anggota karang taruna bekerja sama dengan kompak dan sepakat mempromosikan usaha karang taruna baik melalui media sosial atau secara langsung. Kerja sama ini kemudian berhasil membuat usaha karang taruna jadi terkenal di masyarakat sekitar. Dengan terkenalnya usaha karang taruna, maka permintaan produk menjadi meningkat oleh masyarakat. Meningkatnya permintaan produk ialah karena masyarakat percaya pada produk/jasa tersebut. Dengan begitu tingkat produktivitas usaha karang taruna juga ikut meningkat.

Meningkatnya tingkat produktivitas usaha membuat para anggota kembali saling bantu pada proses produksi. Misal proses produksi telur asin, produksi pada usaha sablon dan percetakan, serta produksi pada usaha las listrik. Kerja sama yang baik dalam proses produksi usaha karang taruna menghasilkan banyak keuntungan (Adi dan Idris, 2021), di antaranya yaitu penghematan tenaga dan waktu serta meningkatnya laba yang didapat. Laba yang berhasil didapat oleh para pengelola usaha karang taruna dapat menambah pemasukan kas karang taruna setiap bulannya. Kas karang taruna yang bertambah setiap bulannya dapat dipergunakan untuk menjalankan program kegiatan atau membuka usaha baru milik karang taruna. 


\section{Manfaat modal sosial bagi perkembangan usaha ekonomi produktif ...}

Sehingga dalam hal ini, jaringan (network) memiliki bagian besar pada keberhasilan usaha ekonomi produktif milik Karang Taruna Guyub Rukun 78 Desa Bantur. Jaringan sosial baik dalam organisasi atau dengan masyarakat di luar organisasi sangat membantu keberhasilan usaha ekonomi produktif milik karang taruna. Keberhasilan usaha adalah tujuan bersama antar anggota karang taruna sekaligus hasil dari pencapaian bersama. Komunikasi dan koordinasi yang baik antar anggota karang taruna dan antara anggota karang taruna dengan masyarakat sekitar menghasilkan keuntungan yang dapat dinikmati bersama. Di sini Karang Taruna Guyub Rukun 78 Desa Bantur dapat semakin mengembangkan dan menambah usaha ekonomi produktif. Sedangkan masyarakat dapat menikmati produk atau jasa ditawarkan Karang Taruna Guyub Rukun 78 Desa Bantur. Kerja sama yang menghasilkan sesuatu yang baik kan sangat mungkin untuk terulang. Inilah kenyataan yang terjadi di dalam organisasi karang taruna. Kerja sama tidak hanya berhenti sampai di sini. Kekompakan dan gotong royong selalu dijalankan dalam tiap kegiatan.

\section{SIMPULAN}

Karang Taruna Guyub Rukun 78 Desa Bantur adalah organisasi kepemudaan yang terbentuk karena dorongan dan dukungan dari para pemuda RW 07 dan RW 08 Desa Bantur. Karang Taruna Guyub Rukun 78 Desa Bantur berhasil membawa pulang Juara III Lomba Karang Taruna Teladan Tingkat Kabupaten Malang pada Desember 2018. Hasil penelitian menunjukkan bahwa mengenai modal sosial yang dimiliki oleh Karang Taruna Guyub Rukun 78 Desa Bantur sehingga mampu berprestasi. Modal sosial tersebut antara lain: a) ketua, wakil, dan para anggota karang taruna memiliki jaringan/hubungan baik dengan para perangkat desa dan kecamatan; b) ketua, wakil, dan para anggota karang taruna selalu kompak dan gotong royong dalam menjalankan tiap program kegiatan; c) ketua, wakil, dan para anggota karang taruna memiliki slogan "Guyub Rukun" dalam segala macam situasi organisasi; d) para anggota karang taruna sangat sopan, santun, dan menjalin hubungan yang baik dengan masyarakat sekitar Desa Bantur; e) para anggota karang taruna terdiri dari pemuda-pemudi yang berpendidikan, kreatif, dan berwawasan luas; f) para anggota karang taruna dengan jiwa kewirausahaan yang tinggi; g) para anggota karang taruna dengan jiwa sosialnya yang tinggi; dan h) para anggota karang taruna peduli terhadap lingkungan sekitar.

Jaringan (network) dalam modal sosial Karang Taruna Guyub Rukun 78 Desa Bantur memberikan banyak sekali manfaat untuk usaha ekonomi produktif milik karang taruna. Manfaat tersebut antara lain: 1) membantu memperkenalkan usaha (produk/jasa) karang taruna kepada masyarakat sekitar; 2) meningkatkan permintaan produk; 3) meningkatkan produktivitas usaha; 4) banyak keuntungan yang didapat, misalnya penghematan tenaga serta waktu; dan 5) menambah pemasukan kas karang taruna setiap bulannya, sehingga dapat dimanfaatkan untuk menyelenggarakan program kegiatan atau membuka usaha baru karang taruna. Rekomendasi dari hasil penelitian ini adalah sangat penting untuk meningkatkan kedisiplinan dalam diri anggota karang taruna. Hal ini penting agar organisasi dapat berkembang ke arah yang lebih baik dan modal sosial yang dimiliki dapat lebih maksimal untuk dimanfaatkan dalam mengembangkan dan memajukan usaha yang dimiliki. 


\section{DAFTAR PUSTAKA}

Bogdan, R. C. \& Sari Knopp Biklen, Qualitative Research for Education: An Introduction to Theory and Methods Boston: Allyn and bacon, Inc, 1982.

Fiedler. 1967. Kepemimpinan Era Modern. Jakarta: Yayasan Kanisius.

Gunawan, T. 2019. Pemudan dan Organisasi: Studi Realitas Kehidupan Pemuda dalam

Berorganisasi di Sebatik Timur, Perbatahasan Indonesia-Malaysia. (Skripsi). Universitas Negeri Malang, Malang.

Adi, K. R., \& Idris, I. 2021. Peran lingkungan keluarga dalam mengembangkan wirausaha muda. Jurnal Teori dan Praksis Pembelajaran IPS, 6(1), 1-8.

Miles, M. B. \& Huberman, A Michael. 2014. Analisis Data Kualitatif: Buku Sumber Tentang Metode-metode Baru. Terjemahan Rohidi. Tjejep Rohendi. Jakarta: Universitas Indonesia Pers.

Moleong, L. J. 2017. Metodologi Penelitian Kualitatif. Bandung: PT Remaja Rosdakarya.

Peraturan Menteri Sosial Republik Indonesia No. 23 Tahun 2013 tentang Pemberdayaan

Karang Taruna. (Online), (http://www.bphn.go.id/data/documents/13pmsos023.pdf), diakses 17 Maret 2019.

Priyono, B. H, Anthony Giddens: Suatu Pengantar, Kepustakaan Poluper Gramedia, Jakarta, 2002.

Ritzer, G. 2012. Teori Sosiologi. Yogyakarta: Pustaka Pelajar.

Soekanto, S. 1985. Perubahan Sosial. Jakarta: Rajawali Pers.

Udoki, S. M. 2014. Pemberdayaan Pemuda melalui Karang Taruna Desa Tunas Jaya Kecamatan Bone Pantai Kabupaten Bone Bolango. Skripsi tidak diterbitkan. Gorontalo: FIP UNG. 